\title{
Justice for Justice Barron Field
}

\author{
Helen Hewson \\ Centre for Plant Biodiversity Research, Plant Industry, CSIRO, \\ Canberra ACT 2601
}

\begin{abstract}
Botanical tributes to Mr Justice Barron Field are reviewed, a correction in Senna is pointed out, and the new combination Senna barronfieldii (Colla) Hewson is made.

\section{Introduction}

It is overdue that we revisit the botanical tributes given to Mr Justice Barron Field (1786-1846), judge in the Supreme Court of New South Wales (1816-1824), to review them and to make a correction. Two genera and one species were named in his honour.

Mr Justice Barron Field took a wide interest in the Colony during his posting. This included observing the plants and animals, composing poetry about them, collecting and drawing them, communicating collections to scientists in Britain and Europe, being a founding member of the Philosophical Society of Australasia and being the inaugural President of the Agricultural Society of New South Wales. Much evidence of this is revealed in his book, Geographical Memoirs on New South Wales (1825) (see also, Desmond (1977) and Currey (1966)). While he seems to have been a controversial figure at judicial, political, sociological and literary levels, his contributions to natural history were sufficiently valued for some scientists to commemorate him by naming some plants in his honour.
\end{abstract}

Fieldia A.Cunn., in Field, Geographical Memoirs on New South Wales 364, t. (Apr. 1825). Type: Fieldia australis A.Cunn.

Syn: Basileophyta F.Muell. Type: B. friderici-augusta F.Muell., $1^{\text {st }} \mathrm{Gen}$. Rept. Veg of the Colony 16 (1853), nom inval., nom. nud.

Fieldia australis A.Cunn., Geographical Memoirs on New South Wales 364, t. (Apr. 1825).

Type: "Blue Mountains ... about twenty-two miles from the entrance of the new route which has recently been traced out by Mr Bell, jr., 1823, A.Cunningham. It is found likewise at the Five Islands or Red-point of the charts."

Cunningham's tribute to Barron Field is as follows: "The name now proposed for the genus is intended to commemorate that of a gentleman who has, in his judicial 
capacity, much aided the advancement of the colony of New South Wales to its present flourishing state; and whose important researches there, in various branches of physical science, will materially tend to confer that interest upon our distant settlement which it so richly deserves, and which yet remains in a great measure to be appreciated."

This was reinforced by Hooker in 1827 when he quoted Cunningham's tribute and stated in a concluding remark regarding his three volume work, Exotic Flora (1821-1827): "To this work do I owe the acquaintance of the gentleman after whom the present plant is named, together with the possession of a valuable collection of New Holland plants, and the use of many excellent drawings made in that country."

Another genus, Fieldia, was described by Gaudichaud-Beaupré and named in Field's honour: Fieldia Gaud., in Freycinet, Voy. Uranie 10: 424, t.36 (1829).

Type: Fieldia lissochiloides Gaud. Type: "In insulis Moluccis (Rawak)."

The name of this genus is a later homonym. The taxon is now regarded as a species of the orchid genus Vandopsis (V. lissochiloides (Gaud.) Pfitzer). Gaudichaud's tribute to Barron Field is as follows: "J'ai consacré ce genre, comme un témoignage de ma profonde reconnaissance, à M. Barron Field, juge de la cour supreme au Port-Jackson, qui nous a facilité les moyens de traverser les Montagnes-Bleus."

From this it is clear that Barron Field assisted members of Louis Freycinet's team to cross the Blue Mountains when they visited the Colony in 1819.

A species in the genus Cassia was also named in Field's honour.

Cassia barronfieldii Colla [as barrenfieldii], Hort. Ripul. App. 2: 343 (Jan. 1826); App. 4: 23, t.11 (July 1830). [Dates follow Stafleu and Cowan (1976).]

Type: "Botany Bay." Symon (1966) indicated that a holotype exists at TO. A specimen at K (bearing no collector detail), transferred from TO, is regarded by Randell (1989) as a syntype. Randell lectotypified the name by this specimen.

Named in "honorem Cl. Barrenfieldii hanc novam pulcherrimamque stirpem dicavi e seminibus absque nimine specifico a Schultesio nissis enatam." And, "in honorem cl. J. C. Barrenfieldio utpote primus qui illam invenerit in regionibus Botany-Bay, ac semina sine nominee praeclaro Schrankio miserit quae nobis humanissimus hic Professor communicaverat."

Bentham (1864: 285) treated this as a taxonomic synonym of C. australis Sims, Bot. Mag. 53: t.2676 (Aug. 1826), and recorded the synonym as "afterwards corrected to C. Fieldii". The correction, noted by Bentham, has not been located. Symon (1966: 102) stated that he found no record of the change; Randell (1989) stated that it was a "nomen nudum"; and Chapman (1991) does not record the name. Similarly any such "correction" is not treated by Vogel (1837). The name C. Fieldii Colla is, however, recorded by Steudel (1841) where he clearly refers back to the C. barrenfieldii of Colla (without specified reference). He also refers to the record of C. barrenfieldii in Vogel. We do not know if Steudel was first to "correct" the name. Nor do we know if Colla published an earlier "correction", as indicated in Index Kewensis (though the record in Index Kewensis is erroneous). Until a specified correction is located in the literature, it is impossible to be sure if C. fieldii is a nom. inval., nom. nud. or, a nom. illeg., nom. 
superfl. It is also possible that the name is based on a different type, though Bentham's use of the term "corrected" does not lend support to this alternative.

More recently, the taxon to which this nomenclatural confusion applies has been treated by Symon (1966) as a taxonomic synonym of Cassia odorata Morris, Fl. Conspicua: t. 57 (Sept. 1826) [date from Stafleu \& Cowan (1976)]. This is currently treated as Senna odorata (Morris) Randell (1989: 202); Harden (1991: 322); and Orchard (1998: 98). The type citation for C. odorata is: "this plant has very recently been introduced from New South Wales; and the present specimen was kindly forwarded by Aylmar Bourke Lambert, Esq., from Boynton House, Wilts, where it flowered in the greenhouse in the month of May." Symon (1966) and Randell (1989) have lectotypified this with the plate, no type specimen having been located. Whilst there is no overt evidence, it is possible that the original material of this taxon was collected by Field. Field did send collections to Lambert (see Miller 1970).

\section{Conclusion}

The Colla epithet predates that of Morris and must take precedence based on the dates indicated by Stafleu and Cowan (1976) The correct name for this taxon is:

\section{Senna barronfieldii (Colla) Hewson comb. nov.}

Basionym: Cassia barronfieldii Colla [as "barrenfieldii"], Hort. Ripul. App. 2: 343 (Jan. 1826). Type: "Botany Bay"; lecto: K, fide Randell (1989).

Cassia australis Sims, Bot. Mag. 53: t.2676 (Aug. 1826) nom. illeg. (non Vellosa (1825)) Type: "from New Holland"; lecto: plate 2676, fide Randell (1989).

Senna odorata (Morris) Randell, J. Adelaide Bot. Gard. 12(2): 202 (1989); Cassia odorata Morris, Fl. Conspicua: t.57 (Sept. 1826). Type: "introduced from New South Wales”; lecto: plate 57, fide Symon (1966), Randell (1989).

The spelling of Field's Christian name is here corrected for the first time. Inadvertently, a nasty jibe was perpetuated by Colla. Amongst Field's enemies in Australia he was taunted with being "barren" of ideas (Elliott 1947), a cruel play on the name of a man who was quite the opposite, as attested in his essays in the Geographical Memoirs. The man may have been irascible but his intellect is defendable. Indications in the literary world (Byrne 1961) that Field "hated botanists", cannot be borne out. His contribution to the knowledge of Australia's flora through botanists, scientists and horticulturists such as Allan Cunningham, William Hooker, Aylmer Lambert, Luigi Colla, Charles Gaudichaud, Josef Schultes and Franz Schrank (representing Australia, Britain, Italy, France and Germany), demonstrate that his contribution was tangible and valued.

\section{Acknowledgments}

I wish to acknowledge the assistance provided by the facilities, library, staff and associates of the Centre for Plant Biodiversity Research where I am an Honorary Associate. 


\section{References}

Bentham G (1864) Flora Australiensis, vol. 2. (Lovell, Reeve \& Co.: London) Byrne JV (1961) Barron Field — Recultivated. Southerly 21(3): 6-18.

Chapman AD (1991) Australian Plant Name Index. (AGPS: Canberra)

Currey CH (1966) In Pike D. (ed.) Australian Dictionary of Biography 1: 73-376. (Melbourne University Press: Melbourne)

Desmond R (1977) Dictionary of British and Irish Botanists and Horticulturists. (Taylor \& Francis: London)

Elliott B (1947) The First Austral Harmonist in Singing to the Cattle. (Georgian House: Melbourne) Field B (1825) Geographical Memoirs on New South Wales. (Murray: London)

Harden GJ (1991) Flora of New South Wales, vol. 2. (New South Wales University Press: Kensington) Hooker WJ (1825-1827) Exotic Flora, vol. 3. (Printed for William Blackwood: Edinburgh; and T. Cadell: London)

Miller HS (1970) The Herbarium of Aylmer Bourke Lambert. Taxon 19: 522.

Orchard AE (1998) (ed.) Flora of Australia, vol. 12. Mimosaceae (excl. Acacia), Caesalpiniaceae. (CSIRO Publishing: Collingwood)

Randell BJ (1989) Revision of the Cassiinae in Australia. J. Adelaide Bot. Gard. 12(2): 165-272.

Stafleu F \& Cowan RS (1976) Taxonomic Literature $2^{\text {nd }}$ edn 1: 523.

Steudel EG (1841) Nomenclator botanicus $2^{\text {nd }}$ edn. (Stuttgardiae et Tubingae)

Symon D (1966) A revision of the genus Cassia in Australia. Trans. Roy. Soc. S. Australia 90: 73-146. Vogel T (1837) Synopsis Generis Cassiae. (Logier: Berlin)

Manuscript received 26 May 2004, accepted 1 February 2005 